УДК 347.21

DOI https: / / doi.org/10.32837/yuv.v0i1.2088

\author{
Г. Крушельницька, \\ кандидат юридичних наук, \\ старший викладач кафедри цивільно-правових дисциплін \\ Національної академії внутрішніх справ
}

\title{
ОСОБЛИВОСТІ ВИНИКНЕННЯ ПРАВА ВЛАСНОСТІ НА ЕМБРІОНИ ЛЮДИНИ IN VITRO
}

Вступ. Стрімкий розвиток науки і технологій у різних сферах людського життя не може не впливати на юридичну доктрину. Виникнення нових об’єктів, щодо яких складаються правовідносини, розширює коло об'єктів цивільних прав, що має враховуватися у цивільному законодавстві. Зокрема, поява допоміжних репродуктивних технологій як спосіб подолання безпліддя призвела до появи такого явища, як ембріони, створені у лабораторному посуді поза живим організмом (in vitro). Після того, як щодо них почали виникати судові спори, перед науковцями постала проблема визначення правового статусу ембріонів in vitro, які пропонувалося розглядати або як суб'єкти права, або як об'єкти правовідносин, або як явище sui generis. Незважаючи на вплив біоетики на сферу права, останнім часом у цивілістиці домінує позиція, що ембріони людини in vitro $є$ об'єктами цивільних прав. Із цієї позиції не можна ігнорувати питання віднесення їх до об'єктів права власності та підстави виникнення права власності на них. Саме тому метою цієї статті є дослідження підстав виникнення права власності на ембріони людини in vitro, з огляду на їх обмежену оборотоздатність.

Варто відзначити, що питання права власності на ембріони in vitro $€$ досить малодослідженим у науці цивільного права, з огляду на складний морально-етичний аспект цієї проблематики. Водночас існує немало праць, присвячених визначенню правового статусу ембріонів in vitro, зокрема як об'єкта цивільних прав. Серед них наукові доробки А.В. Майфата, М.М. Малеіної, Н.В. Аполінської, Ю.Ф. Дружиніної, А.С. Шабанової, В.О. Трубіної, А.Р. Пурге.

Виклад основного матеріалу. Одним із найбільш дискусійних питань у межах дослідження правового статусу ембріонів людини in vitro $€$ ix визнання об'єктом права власності. У зв'язку із відсутністю законодавчого регулювання правового режиму ембріонів in vitro, його формуванням здебільшого займаються суди та вчені-правники. Зокрема, одне із перших судових рішень, які стосувалися правового статусу штучно створених ембріонів, було прийнято в 1988 році судом штату Теннессі (США), який розглянувши справу Davis v. Davis встановив, що людське життя починається 3 моменту зачаття, тканини ембріона володіють такими якостями, як індивідуальність, унікальність, тому людський ембріон не є об'єктом права власності [1, с. 43]. Така позиція суду була підтримана багатьма цивілістами, які вважають, що неможливо говорити про поширення на ембріони in vitro режиму власності, оскільки це прирівнює ї до товару та суперечить морально-етичним нормам $[2$, с. $124 ; 3$, с. $10 ; 4$, с. 31$]$. Ha противагу, штучно створені ембріони визнаються об'єктами права власності здебільшого тими цивілістами, які відносять ембріони in vitro до речей 
[5, с. $134 ; 6$, с. $3 ; 7$, с. 15$]$. Як відзначає Ю.Ф. Дружиніна, спектр правомочностей у володільця прав на ембріони in vitro та порядок іх реалізації дозволяє характеризувати їх як право власності [5, с. 134]. Розглядаючи ембріони in vitro як похідний репродуктивний біоматеріал, В.О. Трубіна також визначає, що вони є об'єктами права власності як і будь-які інші людські біоматеріали [7, с. 15].

Видається, що визначення ембріонів in vitro як особливих об'єктів цивільних прав, що не є речами, також не перешкоджає розглядати їх 3 позицій теорії права власності. Як зазначає Дж. Хофман, і суди на практиці часто використовують поняття власності для вирішення спорів про ембріони, хоча з лінгвістичної точки зору рідко вибирають саме слово «власність» для визначення ембріонів [8, с. 404]. Проте останнім часом суди прямо характеризують ембріони in vitro як об'єкт права власності. Зокрема у 2018 році суд у Садбері (Онтаріо), визнав за жінкою право власності на ембріон, який суд своїм рішенням визначив безпосередньо як «власність» [9]. У 2019 році Апеляційний суд штату Огайо (США) ухвалив рішення по справі за позовом до клініки репродуктивної медицини університетських лікарень в Клівленді у зв'язку зі знищенням тисяч ембріонів через несправність морозильної камери, згідно з яким суд визнав знищені ембріони власністю [10]. Така позиція дійсно узгоджується із практично існуючими відносинами у сфері застосування допоміжних репродуктивних технологій (далі ДРТ), оскільки національними законодавствами більшості країн перебування ембріонів in vitro у цивільному обороті звужується до створення та використання їх виключно з метою лікування безпліддя і договірні відносини, що виникають 3 приводу таких ембріонів, складаються виключно у сфері репродукції. Відповідно, такий стан речей не допускає перетворення ембріонів in vitro у звичайний товар, тому розгляд їх як об'єктів права власності не загрожує комерціалізації такого специфічного об'єкту цивільних прав, проте дозволяе впорядкувати правовідносини, які виникають щодо штучно створених ембріонів людини.

У межах дослідження питання права власності на ембріони in vitro необхідно розглянути підстави набуття права володіння, користування та розпорядження ними. 3 огляду на неврегульованість правового статусу ембріонів людини in vitro у вітчизняному цивільному законодавстві, підстави виникнення права власності на такий специфічний об'єкт цивільних прав можна розглядати лише з точки зору аналогії закону, проте такий підхід в цілому відображає ситуацію, що складається на практиці.

Так, згідно зі ст. 328 ЦК України право власності набувається на підставах, що не заборонені законом, зокрема із правочинів. При цьому в якості підстав для виникнення права власності на ембріон in vitro як на об'єкт, що раніше не існував, Ю.Ф. Дружиніна називає: 1) створення нової речі; 2) переробку речі [5, с. 134]. Із аналізу положень Порядком застосування допоміжних репродуктивних технологій в Україні, затверджених Наказом Міністерства охорони здоров'я від 09.09.2013 № 787 (далі - Порядок застосування ДРТ) можна зробити висновок, що ембріон in vitro може бути створено 3 метою лікування безпліддя на підставі звернення до закладу охорони здоров'я із заявою пацієнта(ки)/ пацієнтів щодо застосування ДРТ. Як зазначає А.П. Головащук, для регулювання правовідносин із надання медичних послуг методами ДРТ укладається договір по надання медичних послуг. Сторонами цього договору є потенційні батьки і заклад охорони здоров'я де проводитимуться відповідні допоміжні репродуктивні 
технології [11, с. 184]. В.І. Біленко вказує, що договір про застосування ДРТ - це правочин, за яким одна сторона бере на себе зобов'язання надати медичну послугу з лікування безпліддя із застосуванням ДРТ, які передбачають здійснення маніпуляцій 3 репродуктивними клітинами з метою запліднення і розвитку ембріонів, а також його виношування, а інша сторона зобов'язана оплатити вказані послуги відповідно до встановлених договором умов [12, с. 4]. Із таким визначенням погоджується M. Заболотна, додатково зазначаючи, що кожен із видів методик лікування безпліддя може бути предметом окремого договору [13, с. 26]. Таким чином, створення ембріонів in vitro відбувається виключно за договором про надання медичних послуг 3 лікування безпліддя із застосуванням ДРТ, що за своєю правовою природою здебільшого є специфікацією.

При цьому постає питання, хто ж набуває право власності на ембріони, створені в результаті реалізації програм ДРТ для лікування безпліддя пацієнтів, оскільки відповідно до Порядку застосування ДРТ для створення ембріонів in vitro використовуються репродуктивні клітини пацієнтів та/або донорів. Так, якщо ембріони створюються із гамет пацієнтів, вони відповідно набувають права власності на них 3 моменту створення. У цьому випадку за аналогією закону доцільно застосовувати положення ст. 332 ЦК України, де визначено, що переробкою $є$ використання однієї речі (матеріалу), в результаті чого створюється нова річ. Право власності на рухому річ, створену особою шляхом переробки 3 матеріалу, що їй не належить, набувається власником матеріалу за його бажанням, якщо інше не встановлено договором або законом. Отже, створення ембріона in vitro із репродуктивних клітин пацієнтів при лікуванні безпліддя шляхом застосування ДРТ, $є$ специфікацією і право власності на них виникає не у закладу охорони здоров'я, а у пацієнтів.

Як відзначає А.С. Шабанова, так само i в разі використання репродуктивного матеріалу донора і пацієнта медична організація не набуває права власності на ембріон in vitro [14, с. 85]. Використання донорських репродуктивних клітин, що надаються закладом охорони здоров'я для створення ембріонів in vitro, доцільно регулювати положеннями ст. 331 ЦК України, де встановлено, що особа, яка виготовила (створила) річ зі своїх матеріалів на підставі договору, $€$ власником цієї речі. Вказана норма $€$ диспозитивною, тому право власності на ембріони in vitro може набуватися пацієнтами, у рамках лікування яких було створено ембріони із донорських гамет. Як вказує Ю.Ф. Дружиніна, особи, які звертаються за наданням медичної допомоги, оплачують в тому числі вартість донорських гамет, якщо є медичні показання до ї використання. Відповідно, у разі використання донорських ооцитів або сперми для створення ембріона, медична організація передає право власності на них особам, яким надається медична допомога, оскільки, використання біоматеріалу оплачується паціентами. Таким чином, на момент створення ембріона права на гамети будуть належати пацієнтам [5, с. 134]. Протилежної думки притримується А.С. Шабанова, яка вважає, що до перенесення донорського ембріона в тіло жінки необхідно визнавати ембріон власністю медичної організації. До створення донорського ембріона, після дачі згоди донора на використання його репродуктивного матеріалу, сперма або ооцити вже знаходяться у власності медичної організації, тому доцільно визнавати право власності на донорський ембріон за медичною організацією як право власності на нову річ [14, с. 85]. Видається, що позиція Ю.Ф. Дружиніною є більш вдалою та обгрунтованою, тому ембріони in 
vitro, створені у межах програм ДРТ, незалежно від того, із чиїх репродуктивних клітин їх створено, належать пацієнтам програм запліднення in vitro.

Доцільно також розглянути, чи можливе набуття закладом охорони здоров'я права власності на ембріони in vitro на підставі ст. 344 ЦК України. Так, статтею 344 ЦК України передбачається, що у випадку заволодіння особою майном на підставі договору 3 його власником, який після закінчення строку договору не пред'явив вимоги про його повернення, вона набуває право власності за набувальною давністю на рухоме майно через п'ять років з часу спливу позовної давності. У свою чергу, Порядком застосування ДРТ передбачено можливість заморожування ембріонів in vitro та ї зберігання за заявою на кріоконсервацію ембріонів, що міститься у Додатку 21 до зазначеного Порядку. Зокрема, у цій заяві зазначається, що заявник/ заявники укладають із закладом охорони здоров'я договір на кріоконсервацію ембріонів, у якому, серед іншого, встановлюється строк їх зберігання. При цьому можлива тривалість зберігання ембріонів науково не встановлена, на практиці лише рекомендується обмежити ii 3-5 роками. Однак перевищення рекомендованого терміну зберігання кріоконсервованих ембріонів не означає їх непридатність до імплантації після розморожування, адже відомі випадки, коли діти народжувалися із ембріонів, заморожених більше двадцяти років тому [15]. Тому постає питання: що відбувається у ситуації, коли пацієнт(ка)/ пацієнти після закінчення строку договору про кріоконсервацію ембріонів in vitro не пред'являють жодних вимог щодо них. На нормативному рівні така ситуація не врегульована, проте законодавцем у заяві на кріоконсервацію ембріонів (Додаток 21 до Порядку застосування ДРТ), пропонується підтверджувати заявникам, що вони інформуються про припинення закладом охорони здоров'я зберігання ембріонів після закінчення зазначеного у договорі строку. При цьому подальша доля заморожених ембріонів, строк зберігання яких пацієнтами не подовжено, законодавцем не визначається. Видається можливим, що такі «покинуті» ембріони за аналогією закону мають утилізуватися закладом охорони здоров'я як відходи категорії В, визначені у Державних санітарно-протиепідемічних правилах і нормах щодо поводження 3 медичними відходами, затверджених Наказом Міністерства охорони здоров'я України 08.06.2015 № 325. Водночас законодавством не врегульовано вимоги до положень договору про кріоконсервацію, який укладається після звернення із відповідною заявою. Таким чином, сторони цього договору можуть визначити, що після закінчення встановленого терміну зберігання заморожених ембріонів, у випадку, якщо пацієнт(ка) / пацієнти не пред'являть жодних вимог на свої ембріони, то заклад охорони здоров'я, що здійснює кріоконсервацію, не зобов'язаний знищувати невитребувані кріоембріони. У такому випадку, якщо після закінчення строку договору власники ембріонів не пред'являть вимоги про їх повернення, заклад охорони здоров'я може набути право власності на них за набувальною давністю через п'ять років з часу спливу позовної давності. Схожа позиція висловлювалася ще у Звіті Комітету Варнока (Великобританія) 1984 року, де рекомендувалося дозволити парі зберігати ембріони для свого майбутнього використання не більше десяти років, після чого право на їх використання та розпорядження ними повинно переходити до установи, що здійснює їх зберігання. У подальшому Уряд Великобританії висунув пропозицію, згідно якої «закон повинен грунтуватися на чіткому принципі першорядності бажань донора протягом встановленого 
терміну зберігання ембріонів; після закінчення даного терміну право на ї використання в інших цілях переходить до власника ліцензії за умови попередньої згоди донора», яка була закріплена в Акті про зачаття людини та ембріологію 1990 року [16, с. 23].

Ще однією підставою набуття права власності на ембріони in vitro $€$ ї донація. Так, розділом V Порядку застосування ДРТ передбачено, що донори за письмово оформленою добровільною згодою надають свої ембріони для використання в інших осіб при лікуванні безпліддя. Донорами ембріонів можуть бути пацієнти програми запліднення in vitro, у яких після народження дитини залишаються у кріобанку невикористані кріоконсервовані ембріони. За добровільною, усвідомленою, письмово оформленою інформованою згодою пацієнтів-донорів, ембріони, утворені внаслідок запліднення донорських ооцитів спермою донора, можуть бути використані для донації безплідній пацієнтці/подружній парі-реципієнту, а також жінкам-реципієнтам, які не перебувають у шлюбі. Таким чином, законодавством України передбачається можливість відчуження кріоконсервованих ембріонів in vitro, які мають генетичний зв'язок із донорами ембріонів або не мають такого зв'язку. Із заяви, форма якої міститься у додатку 11 до Порядку застосування ДРТ, випливає, що донорство може бути як анонімним, так і відкритим, а дозвіл на використання ембріонів у лікувальних програмах ДРТ для інших пацієнтів надається донорами закладу охорони здоров'я. У цьому випадку виникає питання, до кого переходить право власності на кріоембріони in vitro внаслідок їх донації. Видається, що в разі анонімного донорства право власності на такі ембріони набуває заклад охорони здоров'я з моменту підписання донором/донорами інформованої згоди пацієнтів на використання їхніх ембріонів у лікувальних програмах
ДРТ в інших пацієнтів. У випадку анонімного донорства заклад охорони здоров'я продовжує зберігання донованих кріоембріонів за свій рахунок до моменту розморожування та імплантації визначеній пацієнтці, а також має право у будь-який момент припинити їх зберігання. Що стосується відкритого донорства, то в цьому випадку право власності на кріоембріони набувається конкретними пацієнткою/ пацієнтами, які можуть звернутися до закладу охорони здоров'я із заявою про застосування ДРТ із ембріонами донорів з метою їх подальшої імплантації пацієнтці, можуть продовжити зберігання донованих ембріонів, уклавши відповідний договір із закладом охорони здоров'я, можуть надати згоду на використання донованих ембріонів при лікуванні безпліддя у інших пацієнтів, а можуть і відмовитися від права власності на доновані ембріони, припинивши виконувати зобов'язання за договором їх зберігання. Варто відзначити, що донація ембріонів нагадує конструкцію договору пожертви, за яким певне майно безоплатно передається пожертвувачем іншій стороні для досягнення нею певної, наперед обумовленої мети.

Необхідно також розглянути, чи може набуватися право власності на ембріони in vitro в порядку спадкування. Так, за загальним правилом, встановленим статтею 1218 ЦК України, до складу спадщини входять усі права та обов'язки, що належали спадкодавцеві на момент відкриття спадщини i не припинилися внаслідок його смерті. Із цієї точки зору ембріони in vitro як об'єкт цивільних прав нібито теж охоплюються поняттям спадщини, проте видається, що можливість включення їх до складу спадшини залежить від наявності або відсутності генетичного зв'язку спадкодавця 3 ембріонами in vitro. Зокрема, у справі «Паррілло проти Італії (2002) Європейський суд з прав людини зазначив, що ембріони in vitro містять генетичний матеріал 
відповідної особи і тому становлять складову частину генетичного матеріалу цієї людини та ї біологічної ідентичності [17]. Крім того, використання таких ембріонів нерозривно пов'язано із особистими немайновими репродуктивними правами людини на батьківство та материнство, які, у свою чергу, не включаються до складу спадщини. Так само вважає Є.Ю. Петров, вказуючи, що розпорядження щодо ембріона $є$ розпорядженнями немайнового характеру, що підлягають включенню до заповіту як modus [18] .Саме тому право власності на ембріони in vitro, що генетично пов'язані 3 особою спадкодавця, не можуть включатися до складу спадщини за замовчуванням, а їхня доля після смерті одного або обох потенційних батьків має вирішуватися відповідно до положень договору із закладом охорони здоров'я, у якому відбувалося лікування із застосуванням ДРТ. На думку Ю.Ф. Дружиніної, у разі смерті одного з потенційних батьків право спільної сумісної власності має припинятися. Оптимальним $€$ перехід прав до другого потенційного батька/матері. [5, с. 140]. Як зазначає Дж. Хофман, жоден із батьків не має права уникати біологічного батьківства, якщо вони добровільно брали участь в репродуктивній діяльності, чим власне й висловили свою волю на розпорядження репродуктивними правами [8, с. 405]. Проте суди виходять саме з позицій теорії взаємной згоди, згідно з якою пацієнти, укладаючи договір із закладом охорони здоров'я, повинні одразу передбачити подальшу долю невикористаних ембріонів на випадок розірвання шлюбу, смерті чи настання інших обставин, що мають істотне значення для сторін. До таких висновків прийшов і Апеляційний суд Іллінойса (США) в справі Szafranski v. Dunston, і суд НьюЙорка у справі Kass v. Kass, які ухвалили, що попереднє рішення пари, яке було записано в контракті з клінікою репродуктивного здоров'я, повинно мати пріоритет [19]. У 2018 році в Ростові-на-Дону (РФ) судом розглядалася справа за позовом пацієнтки програми запліднення in vitro, яка після смерті чоловіка звернулася до клініки із заявою про проведення процедури запліднення in vitro. Закладом охорони здоров'я їй було відмовлено, оскільки підписані парою документи містили домовленість подружжя про знищення біоматеріалу в разі смерті одного з подружжя. Жінка звернулася до суду, оскільки не була згодна з такими умовами і просила визнати ембріони частиною спадщини, проте суд відмовив у задоволенні позовних вимог, не визнав ембріони частиною успадкованого майна та ухвалив утилізувати біоматеріал [4, с. 31].

Що стосується можливості спадкування ембріонів in vitro, які не мають генетичного зв'язку із спадкодавцем, оскільки створені із донорських ооцитів та сперміїв, то видається, що право власності на такі ембріони після смерті одного з пари пацієнтів, що мали намір народити спільну дитину за допомогою ДРТ, має переходити до другого з пацієнтів. Після смерті обох таких пацієнтів право власності на ембріони in vitro, створені із донорських репродуктивних клітин, повинно переходити до закладу охорони здоров'я із можливістю подальшої імплантації як донорських ембріонів. У будь-якому випадку, подальша доля таких ембріонів після смерті пацієнтів має бути зазначена у договорі із закладом охорони здоров'я. Проте якщо такого розпорядження на випадок смерті зроблено не було, право власності на «сирітські» ембріони має набуватися закладом охорони здоров'я. Такий вдалий підхід закріплювався в австралійському Акті про безпліддя (медичні процедури) ще у 1984 році та зарекомендував себе із найкращого боку, усунувши прогалини, які існували у законодавстві на той час [20, с. 106].

Висновки. На підставі усього вищевикладеного можна стверджувати, 
що ембріони людини in vitro як особливий об'єкт цивільних прав виступають об'єктами права власності, які обмежені в обороті шляхом законодавчого визначення вузького кола осіб, у власності яких можуть перебувати ембріони in vitro, що зводиться до учасників правовідносин у сфері застосування ДРТ при лікуванні безпліддя. Право власності на штучно створені ембріони може набуватися у пацієнтів програм запліднення in vitro на підставі статей 331 та 332 ЦК України, якими регулюється набуття права власності на новостворені речі. У цьому випадку йдеться про аналогію закону, оскільки з огляду на специфічність ознак ембріонів in vitro як об'єктів цивільних прав, вони не можуть визнаватися речами. Крім того, право власності на штучно створені ембріони може набуватися у закладу охорони здоров'я за набувальною давністю, якщо після закінчення строку договору про кріоконсервацію (заморожування та зберігання) пацієнти не заявили свої права на ембріони, а заклад охорони здоров'я не утилізував їх. Також право власності на ембріони in vitro може набуватися пацієнтами програм ДРТ на підставі відкритої донації ембріонів, а закладом охорони здоров'я - на підставі анонімної донації. У порядку спадкування право власності на штучно створені ембріони може набуватися у певних випадках, якщо у спадкодавця та ембріонів відсутній генетичний зв'язок. Вказані вище положення доцільно окремо передбачити у цивільному законодавстві, оскільки відсутність правового регулювання може породити зловживання у сфері відносин власності щодо ембріонів людини in vitro.

У статті досліджено питання віднесення ембріонів людини, створених поза людським організмом в умовах in vitro, до об'єктів права власності. Автором аналізуються дві протилежні позиції, щзо скла- лися у судовій практиці та в доктрині циивільного права, що стосуються можливості віднесення ембріонів in vitro до власності суб'єктів цивільних правовідносин. Оскільки автор притримується niдxоду, згідно з яким ембріони in vitro $\epsilon$ об'єктами цивільних прав $i$ можуть перебувати у власності чітко визначеного законом обмеженого кола осіб, у статті аналізуються підстави виникнення права власності на такий специфічний об'єкт. Автором застосовується аналогія закону, оскільки жоден із наявних правових режимів об'єктів цивільних прав не може поширюватися на штучно створені ембріони людини. Зокрема, у статті розглядається набуття права власності на ембріони in vitro шляхом специфікаціі, оскільки вони на підставі договору створюються в закладі охорони здоров'я в умовах in vitro iз репродуктивного матеріалу, наданого пацієнтами, або із донорських гамет, в результаті чого виникає новий об'єкт. Залежно від власника репродуктивних клітин, із яких створюються ембріон, визначаються суб’єкти права власності на них. Також автором досліджується можливість набуття закладом охорони здоров'я права власності на "покинуті» ембріони in vitro в порядку набувальної давності, у випадку, якщо після закінчення строку дії договору про кріокосервацію, пацієнти не заявили прав на свої кріоембріони, а заклад охорони здоров'я не вжив заходів щодо їх утилізації. Окрема увага приділена донації ембріонів як підставі виникнення права власності на них, а також встановленню власника донованих ембріонів залежно від виду донорства (відкритого чи анонімного). У статmі аналізується можливість виникнення права власності на ембріони in vitro в порядку спадкування, зокрема автором розглядається 
доктринальний та судовий підхід до вирішення изієі проблеми, на підставі чого робиться обтрунтований висновок, що наявність генетичного зв'язку між спадкодавцеем та його ембріонами in vitro впливає на визначення їх подальшої долі.

Ключові слова: ембріон in vitro, допоміжні репродуктивні технології, об'єкти цивільних прав, право власності, підстави виникнення права власності.

\section{Krushelnytska H. Specific features of the ownership rights on human embryo in vitro}

The article investigates the issue of attributing human embryos created outside the human body (in vitro) to the objects of property rights. The author analyzes two opposite positions that have developed in judicial practice and in the doctrine of civil law, concerning the possibility of attributing embryos in vitro to the property of subjects of civil relations. Since the author adheres to the approach according to which embryos in vitro are objects of civil rights and can be owned by a clearly defined law of a limited circle of persons, the article analyzes the grounds for the emergence of ownership of such a specific object. The author applies the analogy of the law, since none of the existing legal regimes of objects of civil rights can be applied to artificially created human embryos. In particular, the article discusses the acquisition of ownership of embryos in vitro through specification, since they are created in a healthcare facility in vitro from reproductive material provided by patients or from donor gametes, resulting in a new object. Depending on the owner of the reproductive cells from which the embryo is created, the subjects of ownership of them are determined. The author is also investigating the possibility of acquiring by a healthcare institution of ownership of abandoned embryos in vitro in the order of acquisitive prescription, if at the end of the term of the cryopreservation agreement, the patients did not claim their rights to their cryoembryos, and the healthcare institution did not take measures to dispose of them. Particular attention is paid to the donation of embryos as the basis for the emergence of ownership of them, as well as the establishment of the owner of donor embryos, depending on the type of donation (open or anonymous). The article analyzes the possibility of the emergence of ownership of embryos in vitro in the order of inheritance, in particular, the author considers a doctrinal and judicial approach to solving this problem, based on which a reasonable conclusion is made that the presence of a genetic link between the testator and his embryos in vitro affects the determination of further the fate of these embryos.

Key words: in vitro embryo, assisted reproductive technologies, objects of civil rights, property rights, grounds for the emergence of property rights.

\section{Література}

1. Еремеева О.И., Сайфуллина Н.А. $K$ вопросу о понятии и правовом положении эмбриона человека. Международный научный журнал «Инновационная наука». № 3. 2016. C. 40-44.

2. Белова Д.А. Правовая природа ембриона in vitro. Lex Russia. 2019. №151. C. $122-130$.

3. Квіт Н.М. Цивільно-правові форми створення та використання біобанків в Україні : автореф. Әис. ... док. юрид. наук : 12.00.03. Львів, 2020. $40 \mathrm{c}$.

4. Пожиткова А.И., Броева Н.О. Эмбрион: наследство или наследник? Юридические науки: проблемы и перспективы : IX Междунар. науч. конф. (г. Казань, июнь 2020 г.). Казань : Молодой ученый, 2020. 46 c.

5. Дружинина Ю.Ф. Правовой режим эмбриона in vitro. Журнал российского права. 2017. № 12. С. 134.

6. Шабанова А. С. Правовой режим эмбриона человека in vitro: общие документы по правам человека и национальное 
право. Journal of Legal and Economic Studies. 2019. № 3 .

7. Трубина В.А. Ткани и органь человека как объекты гражданский прав : автореф. дис. ... канд. юрид. наук : 12.00.03. Москва, 2020. 26 с

8. Hoffman, Jessica R. You Say Adoption, I Say Objection: Why the Word War Over Embryo Disposition Is More Than Just Semantics. Family Law Quarterly, 2012. vol. 46, №. 3, pp. 397-417.

9. Scott Price. Embryos Are Now Considered Property Under The Law (2018). URL: https: / / ww.pallettvalo.com/ whats-trending / embryos-are-nowconsidered-property-under-the-law/ (Jama звернення: 17.01.2021).

10. Richard Vaughn. 24 May 2019 Ohio Appeals Court Affirms Embryos are not Persons (2019). URL: https:// www.iflg.net / ohio-appeals-court-deniesembryo-personhood/ (дата звернення: 17.01.2021)

11. Головащук А.П. Цивільно-правове регулювання відносин, пов'язаних із застосуванням допоміжних репродуктивних технологій : дис. ... канд. юрид. наук: 12.00.03. Київ, 2018. 258 c.

12. Біленко B.I. Договірне регулювання відносин, що виникають у звязку із застосуванням допоміжних репродуктивних технологій : дис. ... канд. юрид. наук: 12.00.03. Київ, 2018. 227 c.

13. Заболотна М. Договірне регулювання відносин із реалізації репродуктивних прав. Підприємництво, господарство i право. 2020. № 7. С. 24-28.
14. Шабанова А.С. Правовое положение донорского репродуктивного матеpuaлa. Matters of Russian and International Law. 2019, Vol. 9, Is. 7A. C. 82-90.

15. Холли Хондерич. Младенеи, которому 27 лет. В США появилась на свет девочка, ждавшая рождения дольше всех в мupe. URL: https://www.bbc.com/ russian/nеws-55168389 (дата звернення: 15.01.2021).

16. Проблемы биоэтики в свете судебной практики Европейского суда по правам человека. 2016. URL: https:// www.echr.coe.int / Documents / Research_ report_bioethics_RUS.pdf (Jата звернення: 15.01.2021).

17. Постанова ЄСПЛ від 27 серпня 2015 р. по справі «Парілло проти Італії» (скарга № 46470/11). Прецееденти Європейського Суду з прав людини. 2015. № 12 .

18. Петров Е.Ю. Сделки mortis causa. Бандо М.В., Брюхов Р.Б., Валеева Н.Г. u др. Частное право. Преодолевая испьтания. K 60-летию Б.М. Гонгало. Москва, 2016. С. 230.

19. Clint Westbrook. Adoptable Property?: The Problem of Frozen Embryos and Ill-Adapted Adoption Law (2016). URL: hp: / / digitalcommons.law.msu.edu/ king / 262 (дата звернення: 18.01.2021).

20. Browne, Colleen M. and Hynes, Brian J. Legal Status of Frozen Embryos: Analysis and Proposed Guidelines for a Uniform Law. Journal of Legislation, 1991. Vol. 17: Iss. 1, Article 6. 